\title{
Reliability and validity of the Turkish version of the Performance-Oriented Mobility Assessment I
}

\author{
Serap D. Yücel • Füsun Şahin • Beril Doğu • \\ Tülay Şahin • Banu Kuran • Sevda Gürsakal
}

Received: 4 May 2011 / Accepted: 24 January 2012 / Published online: 23 February 2012

(C) European Group for Research into Elderly and Physical Activity (EGREPA) 2012

\begin{abstract}
The Performance-Oriented Mobility Assessment (POMA)-I is widely used assessment tool for evaluation of balance and gait properties. The aim of this study was to translate POMA-I to Turkish and to assess its reliability and validity. People with amputated
\end{abstract}

\author{
S. D. Yücel \\ Physical Medicine and Rehabilitation, Bozüyük Public Hospital, \\ Bozüyük, Turkey \\ e-mail: serapdalgic@gmail.com \\ F. Şahin $(\bowtie)$ \\ Physical Medicine and Rehabilitation, Pamukkale University, \\ Medical School, \\ Denizli, Turkey \\ e-mail: fsnsahin@hotmail.com \\ B. Doğu $\cdot$ B. Kuran \\ Physical Medicine and Rehabilitation, \\ Sisli Etfal Education and Research Hospital, \\ Istanbul, Turkey \\ B. Doğu \\ e-mail: drberilozcan@hotmail.com \\ B. Kuran \\ e-mail: banukuran@gmail.com \\ T. Şahin \\ Physical Medicine and Rehabilitation, \\ Antalya Education and Research Hospital, \\ Antalya, Turkey \\ e-mail: dr_tulin@hotmail.com \\ S. Gürsakal \\ Deparment of Econometrics, Uludag University Faculty \\ of Economics and Administrative Sciences, \\ Bursa, Turkey
}

lower extremities using prosthetics, those who underwent orthopedic surgery within the last 6 months, those dependent on wheel chairs and also bed-ridden patients, subjects with dementia and Alzheimer's disease, and illiterate people were excluded. After translation into Turkish, the Turkish version of the scale was applied on the participants at 2-week intervals. Volunteers $\geq 65$ years of age were enrolled in the study. Internal consistencies of POMA subscale scores of postural balance and gait, and total score were calculated using Cronbach's $\alpha$ coefficient. The Turkish version was evaluated with respect to inter- and intrarater reliability and test-retest reliability intraclass correlation coefficient (ICC). For validation, Pearson's correlation coefficient between POMA and Berg Balance Scale (BBS) and Timed Up and Go Test (TUGT) was estimated. Eighty participants enrolled in the study with a mean age of $76.5 \pm 6.75$ years. In the reliability evaluation of the scale, considering postural balance, gait, and total score, Cronbach's $\alpha$ coefficients were found to be 0.72 , 0.83 , and 0.88 , respectively. ICCs were detected above 0.70 for test-retest reliability and also for interrater and intrarater reliability. In validation study POMA total score had a strong positive correlation with BBS total score $(r=0.86, p<0.0001)$, and also a negative correlation with TUGT $(r=-0.75, p<0.0001)$. According to the results of this study, the Turkish version of the POMA-I scale has been found to be a reliable and a valid scale for elderly Turkish people.

Keywords Elderly Older people $\cdot$ Performance-Oriented Mobility Assessment $\cdot$ Reliability $\cdot$ Validity 


\section{Introduction}

Age-related impairments in balance and postural control affect the safe performance of daily activities, and they are the primary reasons responsible for falls $[1,2]$. Every year an average of $28-35 \%$ of the community-living older people ( $>65$ years) are experiencing falls. This incidence increases to $50 \%$ up to 80 years of age. Falls are responsible for $10 \%$ of admissions to emergency rooms, and $6 \%$ of hospitalizations in people aged $\geq 65$ years [3-6].

In many studies, risk factors for falls have been determined. These are classified as intrinsic and extrinsic factors. Muscular weakness of the lower extremities, decreased grip force, impaired postural balance, functional, and cognitive disorders, and visual problems constitute intrinsic factors, while extrinsic factors consist of multiple drug use ( $\geq 4$ drugs) and environmental factors such as inadequate illumination, slippery floors, and lack of safety equipments in bathrooms. Besides, a decrease in the ability to perform daily living activities and usage of walking aids contribute to the frequency of falls $[3,5,7]$.

Tests and functional scales used in proportion to variations in risk factors for falls, and excess numbers of components of postural control are also numerous [8]. One of these scales [Performance-Oriented Mobility Assessment (POMA)-I, see Appendix 1] was developed by Tinetti in 1986 so as to determine the risk of falls [9]. Within a few years (1986-1994), Tinetti made some modifications in the components of POMA to be used as an outcome measure in her research population, developed, tested, and released its various versions [1, 9-14]. Some maneuvers were included or excluded in compliance with the conditions of the population under investigation. These inclusions and exclusions were agreed upon in consideration of consensus among raters.

One of the most widely used versions of POMA is POMA-I or the Tinetti Assessment of Balance and Gait Scale. The POMA-I is used to evaluate older people's ability to maintain postural balance and gait, to identify required interventions to remedy existing disabilities or to document the response to the treatment applied. It is composed of two separate categories as balance and gait tests [15-19]. Balance and gait are evaluated with nine and eight items, respectively. Total score of balance category consists of sitting balance, balance on arising to stand, immediate standing balance (within first $5 \mathrm{~s}$ ), standing balance, maintenance of balance when nudged, standing balance while eyes closed, balance when the subject turns $360^{\circ}$ around him/herself, and tries to sit down from standing position is 16 points. Total score of the gait category which evaluates initiation of gait, step length and height, step symmetry and continuity deviation from a specified path, sways of patient's trunk, and the position of heels while walking is 28 points. As a result, the total score of the scale amounts to 28 points. The highest score indicates the best performance [10]. The aims of this study are both to translate the original English version POMA-I scale into Turkish and also ensure its crosscultural adaptation by the Turkish population in order to establish its validity and reliability.

\section{Material and method}

Etiler Nursing and Rest Home residents and attendants of the older people referred to our clinics (total $n=80$; aged $\geq 65$ years) who consented to participate were included in the study. Written informed consent was obtained from all participants. People with amputated lower extremities using prosthetic leg(s), those who underwent orthopedic surgery within the last 6 weeks, those dependent on wheel chairs and also bed-ridden patients, subjects with dementia and Alzheimer's disease demonstrating difficulty in understanding commands, and illiterate people were excluded from the study.

\section{Evaluation parameters}

In the first examination, age, gender, educational level, occupation, existing diseases of the participants, walking aids used, and the number of falls within the last 6 months were recorded. Ambulatory status of the patients was evaluated using functional ambulation classification (FAC). FAC classifies ambulation in six separate levels as: level 0 -nonfunctional ambulation and level 5ambulator-independent ambulation [20]. Self-assessment scale of well-being evaluated health status of individuals on a five-item scale as: (1) I feel myself very well, (2) my general health status is fine, (3) my health state is of moderate degree, (4) I feel myself sick, and (5) I feel myself very sick.

Balance scale (Berg Balance Scale-BBS) was used for evaluation of balance, and also Timed Up and Go Test (TUGT) was used for measurement of functional mobility. BBS has been developed to be used for the evaluation of functional balance in older people, and it is efficiently employed in many fields of rehabilitation $[15,21,22]$. The BBS scale has been developed with 
the consideration of its fundamental role in the maintenance of different bodily postures during activities of daily life, self-driven spontaneous response to voluntary movements of the trunk and extremities, and postural control. It consists of 14 items. Scoring is done on 5 points allocated according to the ability of the individual to perform tasks independently and/or within a specified time interval. Scores range from 0 (inability to perform the task ) to 4 points ( ability to achieve the task independently within specifed time interval), and total score varies between 0 and 56 points $[15,16,18-19,21-23]$. The BBS scale can be used also for stroke patients and cases with Parkinson's disease or cerebral injuries, in addition to patients at fall risk [17, 23, 24]. The validity and reliability of the Turkish version of this scale which has received a global acceptance in the field of rehabilitation have been already established [23].

TUGT is an easy-to-use balance and gait scale not requiring professional expertise and training. In this test the patient sits in a armchair with a stiff back support whose seat is about $46 \mathrm{~cm}$ above the floor. A marker is placed $3 \mathrm{~m}$ away from the chair. The patient is told to stand from the sitting position, walk to the marker $3 \mathrm{~m}$ away, and then turn around and walk back to the chair, and sit down without hesitation. The time passed during this maneuver is recorded [25-27].

Translation of the original scale into Turkish

Translation and cultural adaptation phases of the Turkish version of the scale were utilized according to previously published articles of Guillemin et al., Beaton et al., and recommendations of the EORTC Quality of Life Group $[8,28,29]$.

At the first step POMA scale was translated independently into Turkish by two native Turkish speakers with a good command of English. Differences between these two Turkish translations were eliminated by a native speaker Turkish physiatrist with a good command of English, and a common Turkish version was formulated. At the second step, the Turkish version was retranslated into English by two native English speakers with a good command of Turkish. Differences between two translated texts were eliminated, and a satisfactory concordance between the Turkish and the original English version was ensured.

Cultural adaptation

After completion of the translation process, the Turkish version was evaluated by eight physiatrists, and ineligible guidelines were pinpointed and reported by each physiatrist individually. Two experienced physiatrists with a good command of English reevaluated ineligible guidelines and made appropriate modifications. The resultant translation was accepted as the final format of the Turkish version.

Reliability study

For the reliability study, the final Turkish version of POMA scale was applied on 80 participants. To establish its interrater reliability, 20 participants were randomized out of 80 and were tested the same day at 15-30-min intervals by two separate assessors. To determine intrarater reliability, 20 participants were randomized out of 80 and were evaluated by the same assessor two times (in the morning and afternoon) in the same day. For the determination of test-retest reliability, all participants were reevaluated 2 weeks after the first assessment.

\section{Validation study}

For construct validity, correlation of the Turkish version of POMA with BBS and TUGT was examined.

\section{Statistical evaluation}

Data obtained from this study were analyzed using SPSS 13.0 Statistical Package program. For the evaluation of demographic characteristics of the participants, descriptive statistical methods (means, standard deviation) were used. Internal consistency and inter- and intrarater reliability of the scale were estimated by using Cronbach's $\alpha$ coefficient and intraclass correlation coefficient (ICC), respectively. ICC was calculated for the evaluation of test-retest reliability of the scale. Construct validity of the scale with BBS and TUGT was evaluated by using Pearson's correlation. The results were assessed at a significance level of $p<0.05$ with a $95 \%$ confidence interval.

\section{Results}

Eighty participants (64 women, 16 men) were enrolled in the study. Mean age of the participants including 43 housewives and 27 pensioners was $76.5 \pm 6.75$ years (min 65 years, max 95 years). Educational levels of the participants were as follows: primary school $(n=$ $35 ; 43.8 \%)$, high school $(n=27 ; 33.8 \%)$, and university 
$(n=4 ; 5 \%)$. Sixteen participants $(20 \%)$ had not ever attended a school, but all of them were literate. Participants were living in their own homes $(n=31,38.8 \%)$, in an intimate's home $(n=3,3.8 \%)$, or in a nursing home $(n=46,57.5 \%)$.

A medical problem was not encountered in seven participants. The remaining 73 participants had at least one and at most five concomitant diseases. The most frequently seen conditions were hypertension $(n=42)$, heart disease $(n=21)$, osteoarthritis (total $n=16$; hip prosthesis $n=6$, knee prosthesis $n=2$ ), and osteoporosis $(n=14)$. Other concomitant conditions reported in participants were thyroid diseases, hyperlipidemia, cerebrovascular disease, cataract, epilepsy, vertigo, benign prostatic hyperplasia, Parkinson's disease, renal failure, and pulmonary disease. When evaluated according to FAC, majority $(n=51,63.8 \%)$ of the participants were fully independent (level 5). Nine subjects (11.3\%, level 4) were independently ambulatory on a level floor, 13 patients $(16.3 \%$, level 3$)$ were dependent under supervision. The remaining seven individuals $(8.8 \%$, level 2$)$ were dependent on an assistant permanently or occasionally. Of the participants $76.3 \%$ evaluated their general health status as well or moderate.

Fifty-six $(70 \%)$ participants did not use any walking aids, while the remaining participants used canes $(n=20 ; 25 \%)$, Lofstrand $(n=3 ; 3.6 \%)$, and walkers $(n=1 ; 1.2 \%)$. When the number of falls occurring within the last 6 months were interrogated, 58 $(72.5 \%)$ of them did not mention any incident of fall, while 13 participants $(16.3 \%)$ reported one fall incident.Scores assigned to the participants based on assessment scales during their first examinations were shown in Table 1.

The Cronbach's $\alpha$ value estimated for internal consistency in the reliability test was above 0.70 for balance, gait, and total score (Table 2). Estimated inter- and intrarater ICC values for balance, gait, and total scores of the POMA scale were still above 0.70 (Table 3). Test-retest reliability analyses were per-

Table 1 Scores allocated to the participants

\begin{tabular}{lccc}
\hline & Minimum & Maximum & Mean \pm standard error \\
\hline POMA balance & 6.00 & 16.00 & $14.6 \pm 2.4$ \\
POMA gait & 5.00 & 12.00 & $11.1 \pm 1.5$ \\
POMA total & 11.0 & 28.00 & $25.6 \pm 3.6$ \\
BBS & 13.00 & 56.00 & $49.4 \pm 8.3$ \\
TUGT & 6.93 & 36.00 & $12.9 \pm 5.5$ \\
\hline
\end{tabular}

Table 2 Internal consistency of the POMA scale

\begin{tabular}{lc}
\hline & Cronbach's $\alpha$ \\
\hline POMA balance & 0.83 \\
POMA gait & 0.72 \\
POMA total & 0.88 \\
\hline
\end{tabular}

formed for each item of the scale, and ICCs of the total score and subscale scores of balance and gait were calculated (Table 4).

ICCs estimated in the balance subscale for attempts to stand up from a sitting position (item 3 ), turn around $360^{\circ}$ (item 8), in the walking subscale for step length and height (items 2,3), step symmetry (item 4), step continuity (item 5), and walk stance (item 8) ranged between 0.63 and 0.66 , while ICCs were above 0.70 for other items. Total score was found to be 0.99 . Construct validity was evaluated by using Pearson's correlation. POMA total score had strong positive correlation with BBS total score $(r=0.86, p<0.0001)$, and also negative correlation with TUGT $(r=-0.75, p<0.0001$; Table 5).

\section{Discussıon}

Since balance is a multifactorial function, a single test cannot be sufficient for its evaluation. Different types of tests measure diverse aspects of postural control. Balance tests can be grouped based on their types. Static standing balance tests evaluate maintenance of balanced state while standing on different support platforms. However dynamic standing balance tests evaluate continuity of balanced state during movements requiring weight transfer $[16,29]$. Sensorial manipulation tests assess various positions of the trunk and head, eye movements, and also limitations imposed on visual, vestibular, and somatosensorial functions. However tests evaluating functional balance are related to

Table 3 Inter- and intrarater reliability

\begin{tabular}{lll}
\hline & $\begin{array}{l}\text { Interrater intraclass } \\
\text { correlation coefficient } \\
(95 \% \mathrm{CI})\end{array}$ & $\begin{array}{l}\text { Intrarater intraclass } \\
\text { correlation coefficient } \\
(95 \% \mathrm{CI})\end{array}$ \\
\hline POMA balance & $0.86(0.69-0.94)$ & $0.92(0.83-0.97)$ \\
POMA gait & $0.80(0.58-0.91)$ & $0.75(0.48-0.89)$ \\
POMA total & $0.86(0.69-0.94)$ & $0.90(0.78-0.96)$ \\
\hline
\end{tabular}


Table 4 Test-retest reliability

\begin{tabular}{lc}
\hline POMA & $\begin{array}{c}\text { Test-retest reliability } \\
\text { Intraclass correlation coefficient }(95 \% \text { CI })\end{array}$ \\
\hline Balance 1 & 1.00 \\
Balance 2 & $0.88(0.83-0.92)$ \\
Balance 3 & $0.65(0.51-0.76)$ \\
Balance 4 & $0.79(0.70-0.86)$ \\
Balance 5 & $0.70(0.57-0.80)$ \\
Balance 6 & $0.76(0.65-0.84)$ \\
Balance 7 & $0.74(0.62-0.82)$ \\
Balance 8 & $0.65(0.51-0.76)$ \\
Balance 9 & $0.84(0.77-0.90)$ \\
Balance total & $0.88(0.83-0.92)$ \\
Gait 10 & 1.00 \\
Gait 11 & $0.65(0.50-0.76)$ \\
Gait 12 & $0.66(0.51-0.76)$ \\
Gait 13 & $0.66(0.52-0.77)$ \\
Gait 14 & $0.64(0.49-0.75)$ \\
Gait 15 & $0.79(0.69-0.86)$ \\
Gait 16 & $0.94(0.92-0.96)$ \\
Gait 17 & $0.63(0.48-0.74)$ \\
Gait total & $0.92(0.87-0.94)$ \\
POMA total & $0.94(0.90-0.95)$ \\
\hline
\end{tabular}

the scales of mobility and gait, sitting and standing, walking, and stepping over objects which involve ability to perform tasks requiring mobility of the body as a whole [16]. POMA is one of the functional scales used to assess fall risk and functions of postural balance which had been developed firstly in a study where falls had been evaluated prospectively [9].

Before the development of POMA, conventional approaches for the evaluation of mobility disorders were focused on either standard neuromuscular assessment methods (i.e., manual muscle test) or analytic estimations such as computerized gait analyses, while

Table 5 Correlations of the POMA with Berg Balance Scale and Timed Up and Go Test

\begin{tabular}{lll}
\hline & Berg Balance Scale & Tmed Up and Go Test \\
\hline POMA balance & $r=0.840$ & $r=-0.675$ \\
& $p<0.0001$ & $p<0.0001$ \\
POMA gait & $r=0.770$ & $r=-0.772$ \\
& $p<0.0001$ & $p<0.0001$ \\
POMA total & $r=0.866$ & $r=-0.759$ \\
& $p<0.0001$ & $p<0.0001$ \\
\hline
\end{tabular}

performance ability of the individuals was not rated. Tinetti proposed an assessment method based on direct observation of composite maneuvers involving ability of the individual to move safely within the boundaries of his/her vicinity. This method examines components of mobility which an individual might strive hard to perform during his/her daily living activities, and $>$ investigates responses to varying degrees of difficulties imposed by certain maneuvers and at the same time helps to determine potential regulatory interventions such as organization of exercises and/or correction of domestic conditions so as to increase patient's mobility $[1,9,10]$. POMA is an easy-to-use evaluation scale which can be completed after a few trials within less than $15 \mathrm{~min}$ and requires not more than a chair and a chronometer [30].

As is the case in other fields of rehabilitation, to obtain accurate and objective measurements from functional scales used in the evaluation of fall risks and balance impairments, these scales should have certain clinometric properties $[8,15,31]$. Reliability, validity, and sensitivity to change lead the way among these required characteristics. Implementation of the scales for diverse population groups requires, in addition to accurate translation cross-cultural validity, interpretation of the original scale in easily comprehensible terms for the target population and culture [8, 15, 31, 32]. During the process of cultural adaptation phase implemented after the Turkish translation of POMA, appropriateness of the terms used was examined. At this phase the translation of item 7 ("eyes closed at maximum position \#6") of the balance subscale posed a problem. At item 6 standing balance against a slight nudging is tested, and testing of the item 7 is required in case the subject has obtained the best score from testing in item 6 . Therefore if the item 7 is translated into Turkish merely as "gözler kapalı (eyes closed)," it might mean testing individual's balance against nudging while eyes closed. However when the Tinetti's original text is reviewed, this item does not test individual's balance when his/hes eyes closed, but it evaluates his/her standing balance. Therefore the translation of the item 7 was corrected as "standing balance while eyes closed." In the English version of the scale, measurement units "inch" and "feet" are used. When these units are converted to centimeters and meters used in our country, whole numbers cannot be obtained. Therefore complying with the recommendations of the translation committee, values were expressed in both measurement units, and included in the relevant items in order to be faithful to the original version and render the scale more comprehensible. 
Interrelated items of the scale assessing the same functional parameters (i.e., gait or balance) and each item which represents the conceptual frame to be evaluated in a way demonstrate internal consistency of the scale [33]. In our study, internal consistency of balance and gait subscales of POMA was calculated using Cronbach's $\alpha$ coefficient which was 0.83 for balance, 0.72 for gait subscales, and 0.88 for the total score. These estimates demonstrate improved internal consistency of the POMA scale. In the literature any study estimating the internal consistency of POMA scale has not been encountered.

With prolongation of life expectancies, individuals are living longer senescent periods. Since during this relatively longer duration of time the elder people will be probably monitored by different physicians at various time spans, intra- and interrater reliabilities of the scales used should be established. POMA was firstly developed in 1986, and it was then applied on 15 ambulatory participants by two separate assessors and interrater reliability was evaluated. These two assessors were $\geq 90 \%$ in consensus for the scores assigned to the participants $[9,10,15]$. Besides, the POMA scores assigned to the patients were found to be correlated with parameters of musculoskeletal system and neurologic variables (muscular strength of the lower extremities, lumbar extension, neck examination findings, and self-reported mobility status of the patients). In our study, we calculated intraclass correlation coefficient for the study of inter- and intrarater reliability studies, and determined intrarater ICC values for subscale scores of balance (0.86), gait (0.80), and total score (0.86), respectively. ICC values of $\geq 0.70$ are acceptable, and the values we obtained prove the reliability of the Turkish version [34]. In three separate studies involving old population where interrater reliability was tested, higher interrater ICC values of 0.75 and 0.97 were found [30, 35-37]. Another study reported higher ICC values $(>0.80)$ for both intra- and interrater reliability of the POMA scale in Parkinson's disease [38]. In patients with amyotrophic lateral sclerosis, intra- and interrater reliability of the balance subscale were found to be excellent as assessed by ICCs $(>0.90)$ [39].

The Test-retest reliability method means testing the scale used at short or long intervals depending on the components of the scale. For tests evaluating physical performance, instrument usage, and measurement of strength, this time interval should be at least 7 days. For test-retest correlation, usage of intraclass correlation method is advised. The test-retest correlation coefficient should be at least 0.80 . Some authors reported that a reliability coefficient of 0.70 might be sufficient [34]. In related articles, ICC values for test-retest reliability of
POMA scale were found to be 0.88 [36] and 0.93 [40] for total and balance subscale scores, respectively. In our study ICC values for test-retest reliability were above 0.80 (for balance subscale scores 0.88 , CI $95 \%$ $0.83-0.92$; gait subscale scores 0.92 , CI $95 \% 0.87-0.94$; and total score 0.94 , CI 95\% 0.90-0.95).

To demonstrate the validity of POMA scale, the BBS scale developed for the assessment of balance impairment in the elderly with its proven validity and reliability of the Turkish version was used [21-23]. A very significant positive correlation was noted between POMA and BBS total scores $(r=0.86)$ and also balance $(r=0.84)$ and gait $(r=0.77)$ subscale scores. Previous studies conducted by Berg et al. [22, 23] also arrived at a similar conclusion $(r=0.91)$.

TUGT is used widely in the assessment and monitorization of functional mobility in the elderly. In our study, as an another indicator of validity, the correlation between POMA and TUGT scale which is an important tool in the evaluation of risks of fall and can be used in the assessment and monitorization of functional mobility, was investigated. A very significant negative correlation was found between total score, and also balance and gait subscales of POMA with the corresponding parameters of TUGT. This negative correlation means that in case of improvement of postural balance of the individual, higher POMA scores are obtained together with decreased time intervals required for the performance of TUGT tasks. Similarly, in a study conducted by Faber et al. [30], a significant association was found between TUGT and POMA total scores $(r=-0.68)$, balance $(r=-0.66)$, and gait subscale scores $(r=-0.56)$. Also, in a study conducted by Cho et al. [41] a significant negative correlation was detected between total scores of POMA and TUGT $(r=-0.65)$ [41].

In conclusion, in this study, POMA-I scale which is used widely in the prediction of postural balance and risk of fall in the elderly was translated into Turkish, and appropriateness of the Turksih version for the Turkish population was demonstrated. Based on the results of this study, the Turkish version of POMA-I scale was shown as a reproducible, reliable, and a valid scale.

Acknowledgment This study has been presented as poster paper in 17th European Congress European Rehabilitation, Quality, Evidence, Efficacy and Effectiveness. Thanks to Tinetti for her permission of POMA scale translation and validation.

Competing interests The authors declare that they have no competing interests. 
Appendix 1: Performance-Oriented Mobility

Assessment-I-Tinetti Balance and Gait Evaluation

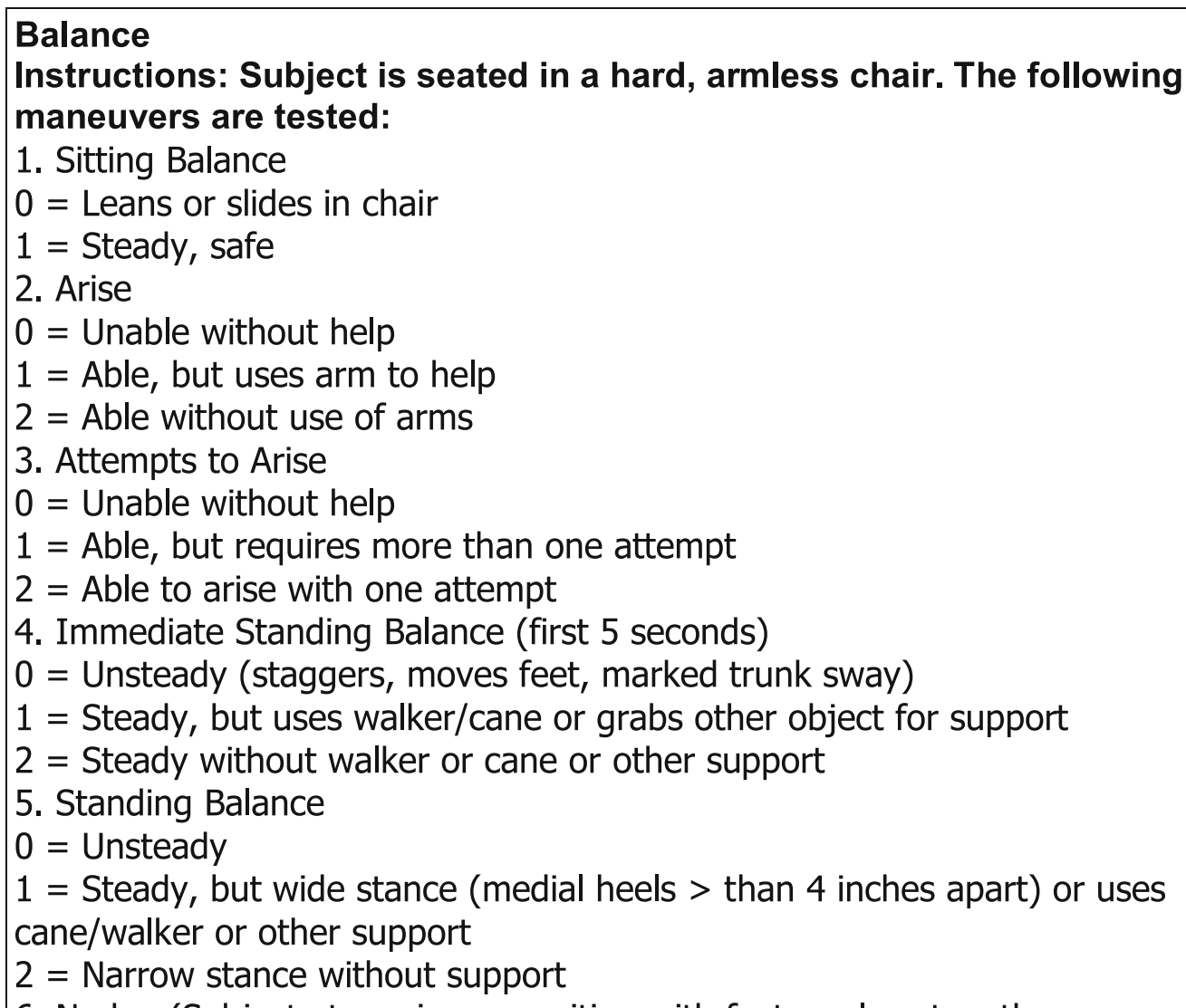

6. Nudge (Subject at maximum position with feet as close together as possible.

Examiner pushes lightly on subject's

sternum with palm of hand 3 times.)

$0=$ Begins to fall

$1=$ Staggers, grabs, but catches self

2 = Steady

7. Eyes Closed (at maximum position \#6)

$0=$ Unsteady

1 = Steady

8. Turn $360^{\circ}$

$0=$ Discontinuous steps

$1=$ Continuous steps

$0=$ Unsteady (grabs, staggers)

1 = Steady

9. Sit Down

0 = Unsafe (misjudged distance; falls into chair)

$1=$ Uses arms or not a smooth motion

2 = Safe, smooth motion

/16 BALANCE SCORE

(C) Copyright; 2006, Mary E. Tinetti, M.D. Reprinted with permission, Mary Tinetti, M.D. 


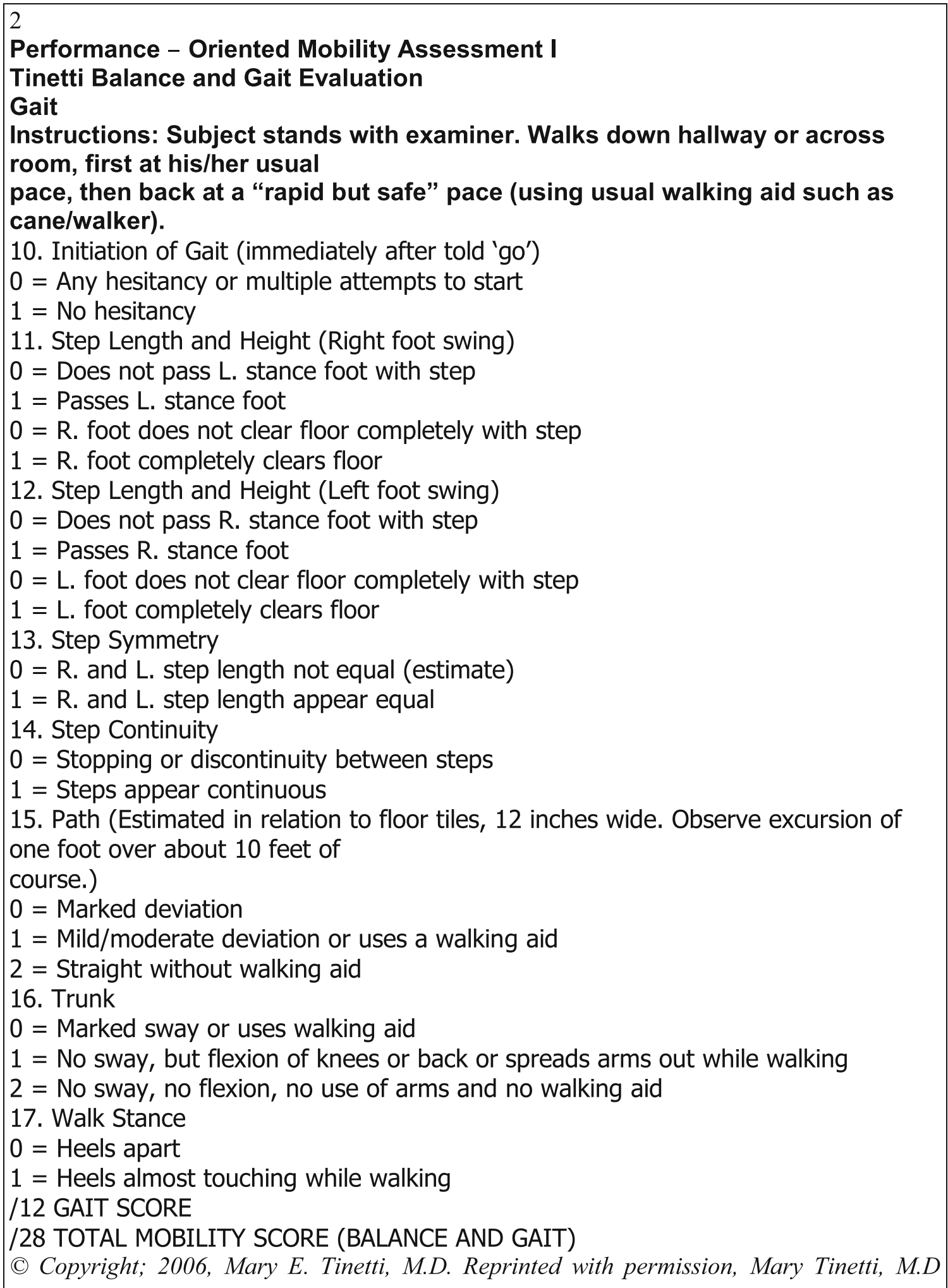




\section{Appendix 2: Performansa Yönelik Hareket \\ Değerlendirmesi I (POMA-I) Tinetti Denge ve Yürüme \\ Değerlendirmesi}

\section{Denge Testi}

Yönergeler: Katılımcı sert, kolsuz sandalyeye oturtulur. Aşağıdaki hareketler test edilir.

1. Oturma dengesi

0 = Sandalyede yaslanıyor veya yana doğru kayıyor

1 = Sabit, güvenilir duruyor

2. Ayağa kalkma

$\begin{array}{ll}0 & =\text { Yardımsız kalkamıyor } \\ 1 & =\text { Kalkabilir, fakat kollarından yardım alır } \\ 2 & =\text { Kollarını kullanma dan kalkabilir }\end{array}$

3. Ayağa kalkma denemeleri

$0=$ Yardımsız yapamıyor

1 = Yapabiliyor, fakat 1'den fazla kez denemesi gerekiyor

$2=$ Tek denemede kalkabiliyor

4. IIlk ayağa kalktığı andaki denge (ilk 5 saniye)

0 = Sabit değil (dengesi bozuk,ayağını oynatıyor, gövdesi sallanıyor)

1 = Sabit, fakat yürüteç/baston kullanıyor veyadestek için başka nesneleri tutıyor

2 = Yürüteç, baston veya başka bir destek olmaksızınsabit

5. Ayakta durma dengesi

0 = Sabit değil

1 = Sabit fakat geniş tabanlı duruş (topukların iç kısmı 4 inç $(10,16 \mathrm{~cm}$ )' ten fazla

ayrık) veya baston/yürüteç veya başka bir destek kullanıyor

2 = Desteksiz dar tabanlı duruş

6. İteleme dengesi (katılımcı ayakları olabildiğince yakın bir şekilde ayakta dururken, değerlendirici katılımcının göğsünden avuç içiyle 3 defa yavaşçäter)
$0=$ Düşmeye başlıyor
1 = Sendeliyor, tutunuyor, fakat kendini tutuyor
$2=$ Sabit

7. Gözler kapalı ayakta denge (madde 6'nın skorunun 2 olması durumunda uygulayınız)

$$
\begin{array}{ll}
0 & =\text { Sabit değil } \\
1 & =\text { Sabit }
\end{array}
$$

8. 360 Derece dönme

$0=$ Devamlı olmayan adımlarla

1 = Devamlı adımlarla

0 = Sabit değil (tutunuyor, sendeliyor)

$1=$ Sabit

9. Oturma

0 = Güvensiz (uzaklığı ölçemiyor, sandalyeye düşüyor)

1 = Kollarını kullanıyor veya yumuşak bir hareketle oturmuyor

2 = Güvenli, yumuşak hareketlerleoturuyor

DENGE SKORU: /16 
Yürüyüş Testi

Yönergeler: Katılımcı değerlendiriciyle beraber ayakta durur, koridorda veya odada yürür, önce "normal" yürüyüş hızıyla gider, sonra "hızlı fakat güvenli" bi r şekilde yürüyerek geri gelir (baston/yürüteç gibi her zamanki yürüyüş desteklerini kullanarak)

10. Yürüyüş başlangıcı (yürümeye başlaması söylendikten hemen sonra)

0 = Herhangi bir tereddütü varsa veya başlamak için birden çok denæryapıyorsa

$1=$ Tereddütü yoksa

11. Adım uzunluğu ve yüksekliği (Sağ ayağını atarken)

0 = Sol ayağını sağ adımıyla geçemiyorsa

1 = Sol ayağını geçiyorsa

0 = Sağ ayağını yerden tamamen kaldıramıyorsa

1 = Sağ ayağını tamamen yerden kaldırabiliyorsa

12. Adım uzunluğu ve yüksekliği (Sol ayağını atarken)

0 = Sağ ayağını sol adımıyla geçmiyorsa

1 = Sağ ayağını geçiyorsa

0 = Sol ayağını yerden tamemen kaldıramıyorsa

1 = Sol ayağını tamemen yerden kaldırabiliyorsa

13. Adım simetrisi

0 = Sağ ve sol adım uzunluğu eşit değil (görsel tahmin)

1 = Sağ ve sol adım uzunluğu eşi görünüyor

14. Adım devamlılığı

0 = Adımlar arasında duraksama veya kopukluk var

1 = Adımlar devamlı görünüyor

15. Yol \{12-inç, $(30,09 \mathrm{~cm})$ genişliğindeki yer karelerine göre tahmin ederek, 1 of lik $(3,048$ metre) alandaki 1 adımdan fazla olan sapmaları gözlembèn\}

0 = Belirgin sapma

1 = Orta derecede sapma veya yürümeye yardımcı cihaz kullanıyor

2 = Yardımcı cihazsız düz yürüyor

16. Gövde

0 = Belirgin biçimde sallanıyor veya yürümeye yardımcı cihazkullanıyor

1 = Sallanmıyor fakat dizlerini veya belini fleksiyona getiriyor veya yürürken kollarını yana açıyor

2 = Sallanmıyor, fleksiyon yok, kollarını kullanmıyor ve yürüme cih azı kullanmıyor

17. Yürüme durumu

$0=$ Topuklar birbirinden ayrı

$1=$ Topuklar yürürken neredeyse birbirine değiyor

YÜRÜYÜŞ SKORU = $/ 12$

DENGE SKORU = 116

TOPLAM SKOR (Yürüyüş + Denge) = 128 


\section{References}

1. Tinetti ME, Speechle M, Ginter SF (1988) Risk factors for falls among elderly persons living in the community. N Engl J Med 319:1701-1707

2. Camicioli R, Panzer VP, Kaye J (1997) Balance in the healthy elderly: posturography and clinical assessment. Arch Neurol 54:976-981

3. American Geriatrics Society, British Geriatrics Society, American Academy of Orthopaedic Surgeons Panel on Falls Prevention (2001) Guideline for the prevention of falls in older persons. J Am Geriatr Soc 49:664-672

4. Tinetti ME, Mendes De Leon CF et al (1994) Fear of falling and fall-related efficacy in relationship to functioning among community-living elders. J Gerontol 49(3):M140-M147

5. Tinetti ME, Williams CS (1997) Falls, injuries due to falls, and the risk of admission to a nursing home. N Engl J Med 337:1279-1284

6. World Health Organization (2008) WHO global report on falls prevention in older age. WHO 2007

7. Tinetti ME, Baker DI, King M et al (2008) Effect of dissemination of evidence in reducing injuries from falls. $\mathrm{N}$ Engl $\mathrm{J}$ Med 359:252-261

8. Beaton DE, Bombardier C, Guillemin F et al (2000) Guidelines for the process of cross-cultural adaptation of self-report measures. Spine 25:3186-3191

9. Tinetti ME, Williams TF, Mayewski R (1986) Fall risk index for elderly patients based on number chronic disabilities. Am J Med 80:429-434

10. Tinetti ME (1986) Performance-oriented assessment of mobility problems in elderly patients. J Am Geriatr Soc 34:119-126

11. Tinetti ME, Ginter SF (1988) Identifying mobility dysfunctions in elderly patients. JAMA 259:1190-1193

12. Tinetti ME, Baker DI, Garret PA et al (1993) Yale Ficsit: risk factor abatement strategy for fall prevention. J Am Geriatr Soc 41:315-320

13. Koch M, Gottschalk M, Baker DI et al (1994) An impairment and disability assessment and treatment protocol for community-living elderly persons. Phys Ther 74(4):57-67

14. Tinetti ME, Baker DI, McAvay G (1994) A multifactorial intervention to reduce the risk of falling among elderly people living in the community. N Engl J Med 331:821-827

15. VanSwearingen JM, Brach JS (2001) Making geriatric assessment work: selecting useful measures. Phys Ther 81:12331252

16. Allison L, Fuller K (2000) Balance and vestibular disorders. In: Umphred DA (ed) Neurological rehabilitation. Aharcourt Health Sciences Company, New York, pp 616-660

17. Hayes KW, Johnson ME (2003) Measures of adult general performance tests. Arthrits Rheum 49:28-42

18. Whitney SL, Poole JL, Cass SP (1998) A review of balance instruments for older adults. Am J Occup Ther 52:666-671

19. Alexander NB, Goldberg A (2006) Clinical gait and stepping performance measures in older adults. Eur Rev Aging Phys Act $3: 20-28$

20. Holden MK, Gill KM, Magliozzi MR (1986) Gait assessment for neurologically impaired patients. Standards for outcome assessment. Phys Ther 66:1530-1539

21. Berg KO, Wood-Dauphinee S, Williams JI, Gayton D (1989) Measuring balance in the elderly: preliminary development of an instrument. Physiother Can 41:304-311
22. Berg KO, Wood-Dauphinee S, Williams JI, Maki B (1992) Measuring balance in the elderly: validation of an instrument. Can J Public Health 83(Suppl 2):7-11

23. Sahin F, Yilmaz F, Ozmaden A et al (2008) Reliability and validity of the Turkish version of the Berg Balance Scale. J Geriatr Phys Ther 31(1):32-37

24. Berg KO, Maki BE, Williams JI et al (1992) Clinical and laboratory measures of postural balance in an elderly population. Arch Phys Med Rehabil 73:1073-1080

25. Podsiadlo D, Richardson S (1991) The timed "up \& go": a test of basic functional mobility for frail elderly persons. J Am Geriatr Soc 39:142-148

26. Wall JC, Bell C, Campbell S, Davis J (2000) The Timed Get-upand-Go test revisited: measurement of the component tasks. J Rehabil Res Dev 37:109-113

27. Shumway-Cook A, Brauer S, Woollacott M (2000) Predicting the probability for falls in community-dwelling older adults using the timed up and go test. Phys Ther 80:896-901

28. Guillemin F (1995) Cross-cultural adaptation and validation of health status measures. Scand J Rheumatol 24(2):64-68

29. Rogers ME, Rogers NL, Takeshima N, Islam MM (2005) Methods to assess and improve the physical parameters associated with fall risk in older adults. Turk J Phys Med Rehab 51(Suppl B):B23-B29

30. Faber MJ, Bosscher RJ, VanWieringen PCW (2006) Clinimetric properties of the performance-oriented mobility assessment. Phys Ther 86:944-954

31. Küçükdeveci A (2005) Quality of life in rehabilitation. J Phys Med Rehab 51(Suppl B):B23-B29

32. Task Force on Standards for Measurement in Physical Therapy (1991) Standards for tests and measurements in physical therapy practice. Phys Ther 71:589-622

33. de Vet HC, Terwee CB, Knol DL, Bouter LM (2006) When to use agreement versus reliability measures. J Clin Epidemiol 59:10331039

34. Bot SD, Terwee CB, van der Windt DA et al (2004) Clinimetric evaluation of shoulder disability questionnaires: a systematic review of the literature. Ann Rheum Dis 63:335-341

35. McGinty SM, Masters LD, Till DB (1999) Inter-tester reliability using the Tinetti gait and balance assessment scale. Iss Aging $22: 3-5$

36. Mecagni C, Smith JP, Roberts KE, O’Sullivan SB (2000) Balance and ankle range of motion in community-dwelling women aged 64-87 years: a correlational study. Phys Ther 80:1004-1011

37. Protas EJ, Harris C, Moch C, Rusk M (2000) Sensitivity of a clinical scale of balance and gait in frail nursing home residents. Disabil Rehabil 22:372-378

38. Kegelmeyer DA, Kloos AD, Thomas KM, Kostyk SK (2007) Reliability and validity of the Tinetti mobility test for individuals with Parkinson disease. Phys Ther 87:1369-1378

39. Kloos AD, Dal Bello-Haas V, Thome R et al (2004) Interrater and intrarater reliability of the Tinetti balance test for individuals with amyotrophic lateral sclerosis. J Neurol Phys Ther 28: $12-19$

40. Harada N, Chiu V, Fowler E et al (1995) Physical therapy to improve functioning of older people in residental care facilities. Phys Ther 75:830-838

41. Cho BL, Scarpace D, Alexander NB (2004) Tests of stepping as indicators of mobility, balance, and fall risk in balance-impaired older adults. J Am Geriatr Soc 52:1168-1173 